\title{
Heterophyiasis, an intestinal fluke infection of man and vertebrates transmitted by euryhaline gastropods and fish
}

\author{
H. Taraschewski \\ Universität Hohenheim, Abteilung Parasitologie; \\ D-7000 Stuttgart 70, Federal Republic of Germany
}

\begin{abstract}
Heterophyes heterophyes, agent of human heterophyiasis in the Near East, is transmitted in marine lagoons and saline inland waters, where the euryhaline intermediate hosts are abundant. In Egypt, mullets, the predominant second intermediate hosts, are customarily consumed raw; thus man becomes infected easily. Symptoms of human infections are usually considered mild. Mullets do not seem to be affected by the metacercariae encysted in the muscles, whereas the growth of the snail host Pirenella conica was found to be enhanced due to the infestation by the trematodes. In laboratory experiments, the flukes were found to be well developed in dogs, foxes and cats, but failed to reach sexual maturity in several other potentially piscivorous mammals and birds. In nature, dogs probably serve as the major reservoir hosts. Heterophyiasis is most prevalent in the Nile Delta, a huge brackish water area which is densely populated by humans and, consequently, also by dogs and cats. In the Far East, besides Heterophyes nocens, several other heterophyids with marine or fresh-water life-cycles are known to infect humans.
\end{abstract}

\section{INTRODUCTION}

At least 14 species of heterophyid trematodes are known from the human intestine. Humans as definitive hosts are affected accidentally, or on a large scale where fish is consumed raw, salted, or insufficiently cooked (chiefly in East Asia and in South-East Asia).

As these 'human' heterophyids are transmitted by prosobranch gastropods of the families Potamididae, Melaniidae, Pleuroceridae and Littorinidae - and subsequently by fish with a similar habitat preference - several species are encountered along the coasts. Still, Cryptocotyle lingua, which was shown to parasitize $6 \%$ of the investigated Eskimos on Greenland (Babbot et al., 1961), is the only species marine biologists have paid attention to adequately.

Among the heterophyids with medical relevance the species most frequently reported from humans are listed in Table 1. As heterophyid eggs of different species may be very similar to each other, infections can often be diagnosed to the species level only, by medical expulsion of the flukes or by autopsy. Only such reports are listed in Table 1.

Mullets, Mugil cephalus for instance, act as the most important second intermediate hosts of Heterophyes spp., Pygidiopsis summa and Stellantchasmus falcatus (Table 1). Metagonimus spp. and Haplorchis yokogawai encyst in fresh water fish. As mullets may 
Table 1. Heterophyidae most frequently reported from the human intestine

\begin{tabular}{|c|c|c|c|}
\hline Fluke species & Snail hosts & $\begin{array}{l}\text { Human cases } \\
\text { reported from }\end{array}$ & $\begin{array}{c}\text { Recent reports or reviews, } \\
\text { remarks }\end{array}$ \\
\hline $\begin{array}{l}\text { Heterophyes } \\
\text { heterophyes } \\
\text { (v. Siebold) } \\
\text { Stiles \& Hassal }\end{array}$ & $\begin{array}{l}\text { Near East: } \\
\text { Pirenella conica } \\
\text { (Potamididae) }\end{array}$ & Near East & $\begin{array}{l}\text { v. Siebold (1852); Looss (1902); } \\
\text { Khalil (1937); Kuntz \& Chandler } \\
\text { (1956a) }\end{array}$ \\
\hline $\begin{array}{l}H . \text { nocens } \\
\text { Onji \& Nishio }\end{array}$ & $\begin{array}{l}\text { Cerithidea cingulata } \\
\text { (= Tympanotonus } \\
\text { micropterus) } \\
\text { (Potamididae) }\end{array}$ & East Asia & $\begin{array}{l}\text { Ito (1964); Yokogawa et al. (1965); } \\
\text { Seo et al. (1981). Often } H \text {. nocens } \\
\text { is considered a subspecies of } \\
H . \text { heterophyes }\end{array}$ \\
\hline $\begin{array}{l}\text { Pygidiopsis summa } \\
\text { Onji \& Nishio }\end{array}$ & $\begin{array}{l}\text { Cerithidea } \\
\text { cingulata }\end{array}$ & East Asia & $\begin{array}{l}\text { Ito (1964); Yokogawa et al. (1965); } \\
\text { Seo et al. (1981) }\end{array}$ \\
\hline $\begin{array}{l}\text { Metagonimus } \\
\text { yokogawai } \\
\text { Katsurada }\end{array}$ & $\begin{array}{l}\text { Semisulcospira } \\
\text { libertina } \\
\text { (Pleuroceridae) }\end{array}$ & Asia & $\begin{array}{l}\text { Ito (1964); Yokogawa et al. (1965); } \\
\text { Seo et al. (1981). Ito (1964): "The } \\
\text { incidence of Metagonimus in the } \\
\text { human body (in Japan) is } \\
\text { considered to be ca } 1 \% \text {, and yet in } \\
\text { certain local areas the incidence } \\
\text { of tens percent is exhibited." }\end{array}$ \\
\hline $\begin{array}{l}\text { M. takahashii } \\
\text { Suzuki }\end{array}$ & $\begin{array}{l}\text { Semisulcospira } \\
\text { libertina }\end{array}$ & East Asia & $\begin{array}{l}\text { Sakai (1962); Ito (1964). In recent } \\
\text { years generally accepted as a } \\
\text { species different from } \\
\text { M. yokogawai (Saito, 1973) }\end{array}$ \\
\hline $\begin{array}{l}\text { Stellantchasmus } \\
\text { falcatus } \\
\text { Onji \& Nishio }\end{array}$ & $\begin{array}{l}\text { Tarebia granifera } \\
\text { and other melaniid } \\
\text { snails }\end{array}$ & Asia, Oceania & $\begin{array}{l}\text { Ito }(1964) ; \text { Kagei et al. (1964); } \\
\text { Tantachamrum \& Kliks (1978) }\end{array}$ \\
\hline $\begin{array}{l}\text { Haplorchis } \\
\text { yokogawai } \\
\text { Katsuta }\end{array}$ & $\begin{array}{l}\text { Melanoides } \\
\text { tuberculatus and } \\
\text { other melanidd snails }\end{array}$ & Asia & $\begin{array}{l}\text { Ito (1964); Manning \& Lertprasert } \\
(1970) ; \text { Manning et al. (1971). } \\
\text { Africa (1938): " } \ldots \text { not only the } \\
\text { most frequently encountered in } \\
\text { man in this country (Philippines) } \\
\text { but also the most frequently } \\
\text { associated with cardiac failure." }\end{array}$ \\
\hline
\end{tabular}

freely migrate between the sea and fresh water, metacercariae of the 'coastal species' may be carried into fresh water as well.

The aim of this paper is to summarize the information on the biology and ecology of Heterophyes heterophyes (Fig. 1), the agent of human heterophyiasis.

\section{HOST RECORDS}

\section{Definitive hosts}

Heterophyes heterophyes was found in Egypt in the human intestine for the first time in 1851 ( $v$. Siebold, 1852). Later on, the number of autopsies mentioned is only 


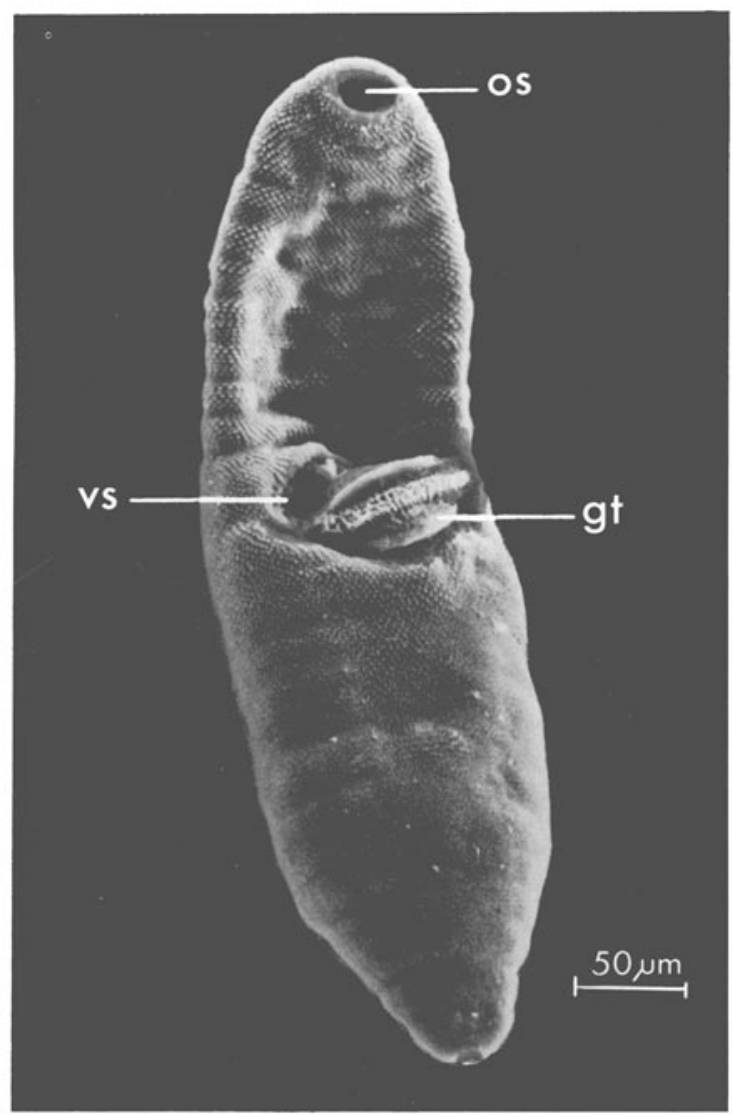

Fig. 1. Heterophyes heterophyes from intestine of a cat taken by a scanning electron microscope. os $=$ oral sucker; vs $=$ ventral sucker; $g t=$ gonotyl (genital sucker)

scarce (Looss, 1902; Khalil, 1937). However, the fluke has been frequently diagnosed by coprological diagnosis (Khalil, 1937; Wells \& Blagg, 1956; Nagathy \& Khalil, 1964; Coble et al., 1968; Sheir \& El-Shabrawy Aboul-Enein, 1970; Rifaat et al., 1980). As the prevalence of other heterophyids in the area in question is lower than that of $H$. heterophyes (Taraschewski, 1984), in Egypt this diagnosis can be accepted as fairly reliable.

Positive dissections of dogs (Abdel Azim, 1938; Kuntz \& Chandler, 1956a; Wells \& Randall, 1956; Fahmy \& Selim, 1959) and cats (Kuntz \& Chandler, 1956a; Wells \& Randall, 1956) have shown that this parasite is not specific to humans.

A few wild mammals and birds were also found to be infected: Vulpes vulpes, Canis aureus, Felis chaus, Milvus migrans (Wells \& Randall, 1956); Pelecanus onocrotalus (Looss, 1902).

Outside Egypt, the fluke has been recorded, in recent years*, only in dogs and to a lesser extent in cats. Mediterranean area: Witenberg (1929); Balozet \& Callot (1939);

* Witenberg (1932) also reported human cases from Palestine (Israel). 
Mimioglu et al. (1959); Deiana (1961); Himonas (1964, 1968, 1977); Jemen: Kuntz \& Chandler (1956a); Iran: Massoud et al. (1982); India, Sri Lanka: Rao \& Ayyar (1932); Maplestone \& Bhaduri (1940); Dissanaike (1961); Sen (1965); Rao \& Anantaraman (1967); Rajasekariah et al. (1974); in India $H$. heterophyes is considered an extremely rare parasite of man (Maplestone \& Bhaduri, 1940); South-East Asia: Segal et al. (1968).

As the taxonomical status of Heterophyes nocens is not sufficiently solved yet, $H$. heterophyes is sometimes recorded from East Asia also. Whenever descriptions of the flukes in question are available, however, it becomes clear that $H$. nocens is meant.

\section{Second intermediate hosts}

Khalil (1923) detected that mullets serve as the second intermediate hosts of $H$. heterophyes. Several species of Mugilidae have been found infected since then (data only from Egypt and Israel available). Paperna \& Overstreet (1981) listed: Mugil cephalus, $M$. capito, $M$. auratus, $M$. saliens, and $M$. chelo as being naturally infected. Mature metacercariae of $H$. heterophyes were also obtained experimentally from Liza subviridis and L. ramada (Taraschewski \& Paperna, 1981).

In addition to these Mugilidae, many species of other euryhaline and marine fishes were recorded as intermediate hosts: Epinephelus enaeus (Serranidae), Tilapia (Sarotherodon) simonis (Cichlidae), Lichia amia, L. glauca (Carangidae), Barbus canis (Cyprinidae) (Witenberg, 1929), Tilapia (Sarotherodon) nilotica, T. zillii, Solea solea (Soleidae), Sciaena aquilla (Sciaenidae) (Wells \& Randall, 1956).

Heterophyid metacercariae, obviously of $H$. heterophyes, were also found in Dicentrarchus labrax, D. punctatus, Sparus auratus, Argyrosoma regius (Paperna \& Overstreet, 1981). Non-mugilid fishes were also described as being susceptible to experimental infections: Gambusia affinis (Poecilioidae) (Khalil, 1937), Fundulus parvipinnis (Cyprinodontidae) (Kuntz \& Chandler, 1956a) and Tilapia (Sarotherodon) mossambica (Taraschewski, 1984).

Usually mullets show the highest intensities of Heterophyes infections (Khalil, 1937; Wells \& Randall, 1956; Paperna \& Overstreet, 1981). As yet, there is no information available on whether Mugilidae are most susceptible or whether it is the habitat preference of these fish which makes them the predominant intermediate hosts.

\section{First intermediate host}

Khalil (1937) found the mud snail Pirenella conica Blainville to be the first intermediate host of $H$. heterophyes. Since then $P$. conica naturally infected with $H$. heterophyes have been mentioned by Martin \& Kuntz (1955); Kuntz \& Chandler (1956a); Martin (1959); Taraschewski \& Paperna (1981, 1982). Quantitative data on specific prevalence of this fluke in different snail populations have been collected by Taraschewski (Fig. 2, Table 2). Contrary to the distribution of the second intermediate hosts, distribution of $P$. conica is limited to the eastern and southern Mediterranean, Red Sea and the Persian Gulf (Taraschewski \& Paperna, 1981). As no other potamidid gastropod is known from the Mediterranean, it can be concluded that this species acts as the only snail host in the Mediterranean. In India, however, Cerithidea cingulata (syn. Tympanotonus micropterus), the host of $H$. (heterophyes) nocens in East Asia (Asada, 1928) 
probably is the first intermediate host. According to Evans et al. (1973), both potamidid snails occur in the Persian Gulf. Thus in this area too, further investigation into the intramolluscan part of the life cycle is desired.

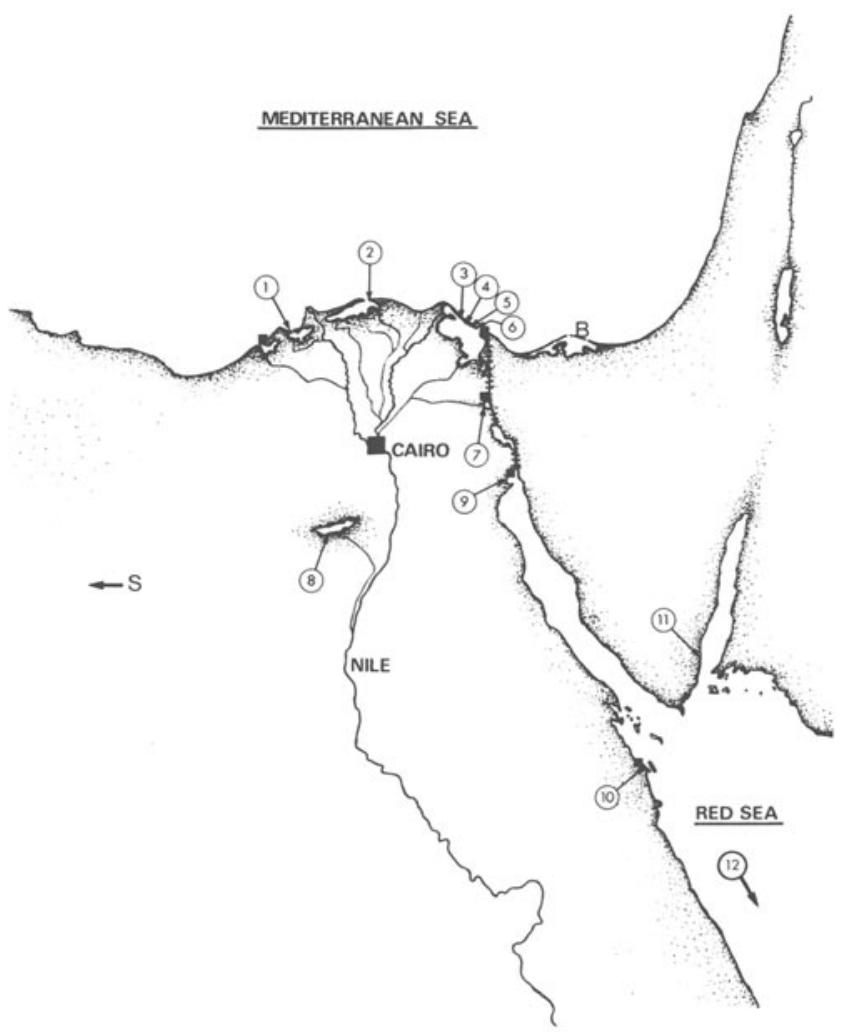

Fig. 2. Populations of Pirenella conica examined for prevalence of Heterophyes heterophyes. For explanations see Table 2. $\mathrm{B}=$ Bardawil Lagoon; $\mathrm{S}=$ Siwa Oasis

\section{ENVIRONMENT OF TRANSMISSION}

As shown by Seo et al. (1981), in Korea prevalence of Heterophyes nocens and Pygidiopsis summa in humans is concentrated along the coast, where Cerithidea cingulata thrives in lagoons and estuaries, while Metagonimus yokogawai is the dominant heterophyid inland. According to Vohra (1970), C. cingulata occurs in a variety of wave sheltered (subsequently soft sediment) habitats 'from brackish water to supersalted fishponds with a salinity range of $15-45 \% 0^{\circ}$, usually in high population densities. In Japan, environmental conditions such as these are chiefly found around the 'Inland Sea' between the major islands, where prevalence of $\mathrm{H}$. nocens in that country is accordingly highest (Ito, 1964).

Pirenella conica is also adapted to lagoon environment (Fig. 3) (Taraschewski \& Paperna, 1981, 1982); however, salinity tolerance also includes the hypersaline range, 
Table 2. Prevalence rate of Heterophyes heterophyes in Pirenella conica in Egypt and Sudan

\begin{tabular}{|c|c|c|c|c|c|c|}
\hline $\begin{array}{l}\text { Sampling } \\
\text { site }\end{array}$ & $\begin{array}{l}\text { Site No. } \\
\text { (see } \\
\text { Fig. 2) }\end{array}$ & $\begin{array}{c}\text { Date of } \\
\text { sampling }\end{array}$ & $\begin{array}{l}\text { No. of } \\
\text { snails } \\
\text { exa- } \\
\text { mined }\end{array}$ & $\begin{array}{l}\text { No. of } \\
\text { snails } \\
\text { shedding } \\
\text { H. hetero- } \\
\text { phyes }\end{array}$ & $\begin{array}{l}\text { Preva- } \\
\text { lence } \\
\text { rate } \\
(\%)\end{array}$ & Habitat type \\
\hline Lake Idku & 1 & $\begin{array}{l}\text { April } \\
1982\end{array}$ & 400 & 27 & 7 & $\begin{array}{l}\text { brackish water lake; rural } \\
\text { environment; } 10 \mathrm{~km} \text { east of } \\
\text { Alexandria }\end{array}$ \\
\hline $\begin{array}{l}\text { Lake } \\
\text { Burullus }\end{array}$ & 2 & $\begin{array}{l}\text { April } \\
1982\end{array}$ & 150 & 57 & 38 & $\begin{array}{l}\text { huge brackish water lake; } \\
\text { sampling station on black mud } \\
\text { off a small town; prevalence of } \\
\text { other trematodes in } P \text {. conica } \\
\text { very low }\end{array}$ \\
\hline \multirow[t]{4}{*}{$\begin{array}{l}\text { Lake } \\
\text { Menzaleh }\end{array}$} & 3 & $\begin{array}{l}\text { Sept. } \\
1981\end{array}$ & 295 & 10 & 3 & \multirow{4}{*}{$\begin{array}{l}\text { huge brackish water lake; } \\
\text { important fishery ground; } \\
\text { distance to the city of Port Said } \\
\text { decreasing from Station } 3 \text { to } \\
\text { Station } 6 \text {; Station } 6 \text { at the } \\
\text { outskirts of the city }\end{array}$} \\
\hline & 4 & $\begin{array}{l}\text { Sept. } \\
1981\end{array}$ & 225 & 10 & 4 & \\
\hline & 5 & $\begin{array}{l}\text { Sept. } \\
1981\end{array}$ & 200 & 27 & 14 & \\
\hline & 6 & $\begin{array}{l}\text { Sept. } \\
1981\end{array}$ & 500 & -80 & 16 & \\
\hline $\begin{array}{l}\text { Lake } \\
\text { Timsah }\end{array}$ & 7 & $\begin{array}{l}\text { Sept. } \\
1981\end{array}$ & 375 & 1 & 0.3 & $\begin{array}{l}\text { saline inland lake in the Suez } \\
\text { Canal; only one population of } \\
P . \text { conica on the bathing beach } \\
\text { of Ismaelia }\end{array}$ \\
\hline $\begin{array}{l}\text { Lake } \\
\text { Qarun }\end{array}$ & 8 & $\begin{array}{l}\text { April } \\
1982\end{array}$ & 650 & 15 & 2 & $\begin{array}{l}\text { saline inland lake; rural } \\
\text { environment; only few } \\
\text { populations of } P \text {. conica }\end{array}$ \\
\hline \multirow[t]{2}{*}{$\begin{array}{l}\text { Suez } \\
\text { beach }\end{array}$} & 9 & $\begin{array}{l}\text { Sept. } \\
1981\end{array}$ & 250 & 1 & 0.4 & \multirow{2}{*}{$\begin{array}{l}\text { northern end of Gulf of Suez; } \\
\text { dense population of } P \text {. conica } \\
\text { on black mud; high } \\
\text { prevalence of other } \\
\text { heterophyids }\end{array}$} \\
\hline & 9 & $\begin{array}{l}\text { April } \\
1982\end{array}$ & 540 & -10 & 2 & \\
\hline $\begin{array}{l}\text { Hurghada } \\
\text { harbor }\end{array}$ & 10 & $\begin{array}{l}\text { April } \\
1982\end{array}$ & 623 & $\sim 12$ & 2 & $\begin{array}{l}\text { fishery harbor of Hurghada; } \\
\text { only a few human settlements } \\
\text { in vicinity; high prevalence of } \\
\text { other heterophyids }\end{array}$ \\
\hline \multirow[t]{3}{*}{$\begin{array}{l}\text { Sinai } \\
\text { Mangrove }\end{array}$} & 11 & $\begin{array}{l}\text { April } \\
1980\end{array}$ & 500 & - & - & \multirow{3}{*}{$\begin{array}{l}\text { marine lagoon fringed by a } \\
\text { mangrove thicket; no human } \\
\text { settlements in vicinity; } \\
\text { abundance of water birds; } \\
\text { high prevalence of } \\
\text { Heterophyes aequalis and } \\
\text { other heterophyids }\end{array}$} \\
\hline & 11 & $\begin{array}{l}\text { April } \\
1981\end{array}$ & 630 & $\sim 3$ & 0.5 & \\
\hline & 11 & $\begin{array}{l}\text { Febr. } \\
1982\end{array}$ & 200 & 1 & 0.5 & \\
\hline $\begin{array}{l}\text { Sudan } \\
\text { Mangrove }\end{array}$ & 12 & $\begin{array}{l}\text { Dec. } \\
1980\end{array}$ & 400 & - & - & $\begin{array}{l}\text { mangrove thicket on } \\
\text { uninhabited island near } \\
\text { Suakin; abundance of water } \\
\text { birds; other heterophyids very } \\
\text { prevalent }\end{array}$ \\
\hline
\end{tabular}




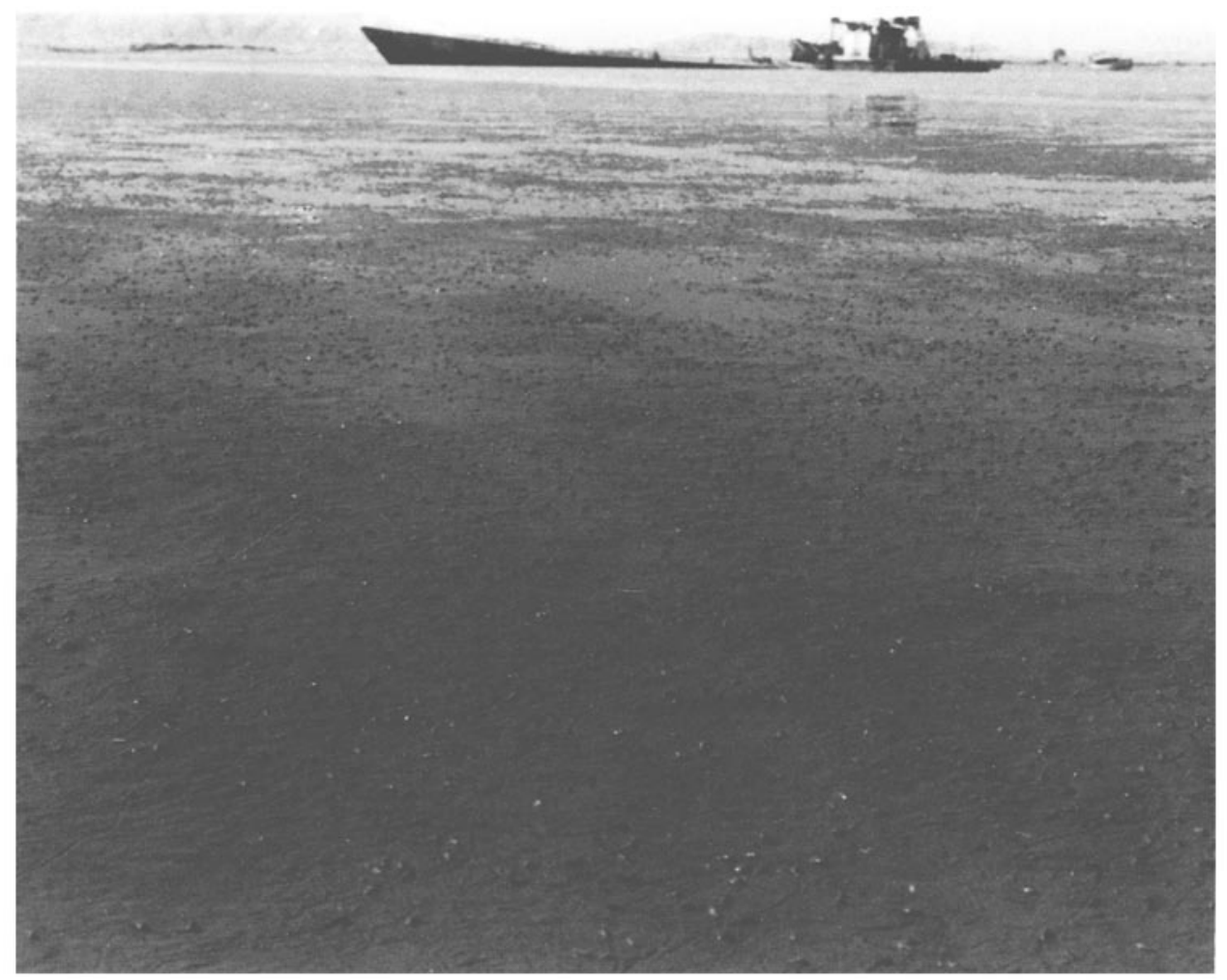

Fig. 3. Pirenella conica (dark dots) on intertidal mud flat (after Taraschewski \& Paperna, 1981)

obviously due to the arid climate of the Near East. It has been shown by field observations and laboratory experiments that this gastropod was able to tolerate a salinity range of $15-80 \%$. $P$. conica also occurs in saline inland waters with an athalassiohalinic ion composition such as Lake Qarun and lakes of the Siwa Oasis (Fig. 2) (Taraschewski \& Paperna, 1981).

Along the Mediterranean Coast, the Nile Delta is the major centre of abundance of $P$. conica; dense populations are found in each of the great brackish water lakes (Fig. 2).

Numerous dense populations of $P$. conica also exist along the sheltered shore of the northern Red Sea. In the Nile Delta, however, the accumulation of first and second intermediate hosts and definitive hosts creates a unique epidemiological situation. The eutrophic lakes serve as nursery and feeding grounds for mullets and other fishes of commercial importance (e.g. Tilapia [Sarotherodon] nilotica) (Khalil, 1937; Paperna \& Overstreet, 1981). Most of the present-day 43 million Egyptians live in the delta surrounded by large numbers of stray dogs and cats. In addition, - contrary to other Mediterranean countries like Tunisia, where it is unusual to consume raw fish (Balozet \& Callot, 1939) - fresh salted mullet 'fessikh' is considered a delicacy by many Egyptians (Khalil, 1937; Rifaat et al, 1980) and is thus probably the most important source of infection to man. According to Khalil (1937), metacercariae inside mullet put on ice 
$\left(2-4^{\circ} \mathrm{C}\right)$ were found still alive and infective after 13 days, in salted fish for a maximum of 7 days.

\section{PREVALENCE OF INFECTION}

\section{Snails}

A survey of different habitats of Pirenella conica in Egypt and Sudan (Taraschewski, 1984) (Fig. 2) revealed, that prevalence of Heterophyes heterophyes was highest in the Nile Delta (Table 2). At Lake Burullus, $38 \%$ of the snails examined* shed cercariae of $H$. heterophyes* *. At Lake Menzaleh on the outskirts of Port Said, about $16 \%$ infection was noted. Prevalence rates decreased with increasing distance to the city of Port Said (Fig. 2, Table 2). At the inland saline lakes Qarun and Timsah, prevalence rates were lower than in the Delta, also on the scarcely populated coast of the Red Sea, where only a few snails were found infected by $H$. heterophyes. At the Red Sea two other Heterophyes spp. $(H$. aequalis, $H$. dispar), which have a more sylvatic cycle are abundant (Taraschewski, 1984).

\section{Fish}

Second intermediate hosts are heavily parasitized by metacercariae of $H$. heterophyes throughout the Delta and the surrounding Sea (Khalil, 1937; Wells \& Randall, 1956; Paperna \& Overstreet, 1981). In the 1950s, prevalence rates of Mugil cephalus and M. capito of Lake Menzaleh (Fig. 2) were found to be $100 \%$ or almost $100 \%$ (Wells \& Randall, 1956); these authors reported similarly high prevalence rates of $H$. heterophyes in fish from the inland Lake Qarun (Fig. 2), where only a few snails were found to be infected in 1982 (Table 2).

As to the intensity, there is only one report available from Bardawil lagoon (Fig. 2), east of the Suez Canal. About 10 years ago, up to 6000 heterophyid metacercariae were recorded per gramm of muscle in Mugil capito and up to about 1000 in $M$. cephalus (Paperna \& Overstreet, 1981). Probably, these enormous parasite burdens were obtained in the adjacent Nile Delta, as the environment of Bardawil lagoon is almost uninhabited. This assumption is supported by the fact that young fish of the lagoon were predominantly infected by Heterophyes aequalis and Stictodora sawakinensis, both of which are shown to be transmitted in a sylvatic kind of environment (Taraschewski, in prep.) such as that at Bardawil lagoon. According to recent spot checks by Paperna (pers. comm.) and by Taraschewski (unpubl.), it seems that the intensity of infection in mullet of that lagoon has been decreasing. East of Bardawil lagoon, on the Israeli coast, where only one epidemiologically isolated population of $P$. conica exists, $H$. heterophyes is also sometimes found in large mullets (Paperna \& Overstreet, 1981), which probably became infected in the Nile Delta. Heterophyid infections in young-of-the-year mullet mostly consisted of Stellantchasmus falcatus (Paperna \& Overstreet, 1981). Cercariae of this species were shown to have the best viability at salinities ranging from $4.5-9.0 \% \mathrm{~S}$ (Lee

* Only snails $>6 \mathrm{~mm}$ in length were collected, as no infection was noted in snails below that minimal size (Taraschewski \& Paperna, 1981, 1982).

* Actual prevalence was probably higher, as not all infected snails will have released cercariae after experimental treatment. 
$\&$ Cheng, 1970), So these infections, obtained in the low salinity estuaries of the Israeli coast, could be autochthonous.

\section{Definitive hosts}

As to the definitive hosts, the first quantitative data on human infections became available in 1937. At that time, up to $90 \%$ of the school children investigated and $22 \%$ of the adults near Lake Menzaleh (Fig. 2) defecated 'Heterophyes eggs' (Khalil, 1937) (Fig. 4). Wells \& Blagg (1956) found Heterophyes eggs in the stools of $36 \%$ of the school children of Baltim at Lake Burullus (Fig. 2). Nagathy \& Khalil (1964) reported about $10 \%$ of the persons investigated near Lake Menzaleh to be infected. Finally Rifaat et al . (1980) found an average of $2.5 \%$ infection in the same area. Thus, like other intestinal helminth diseases of humans the prevalence of heterophyiasis seems to be declining.

From the area of the saline inland lakes, snails of which have been examined by Taraschewski (Fig. 2, Table 2), and the Red Sea, nothing is known about the prevalence of $H$. heterophyes in humans. From the Siwa Oasis, however, about $300 \mathrm{~km}$ inside the Libyan Desert (Egypt), of 42 persons investigated, one defecated Heterophyes eggs (Coble et al., 1968). Although two populations of $P$. conica have been reported from the Siwa Depression (Crawford, 1948; Ibrahim, 1975), it is uncertain whether the case reported by Coble et al. can be considered autochthonous.

Concerning the other vertebrate hosts in Egypt, all quantitative data are older than 25 years. In addition, either the three Egyptian Heterophyes spp. are not treated separately and data of different geographical origin are pooled (Wells \& Randall, 1956). or statements are very general (Kuntz \& Chandler, 1956a). Proportionally large numbers

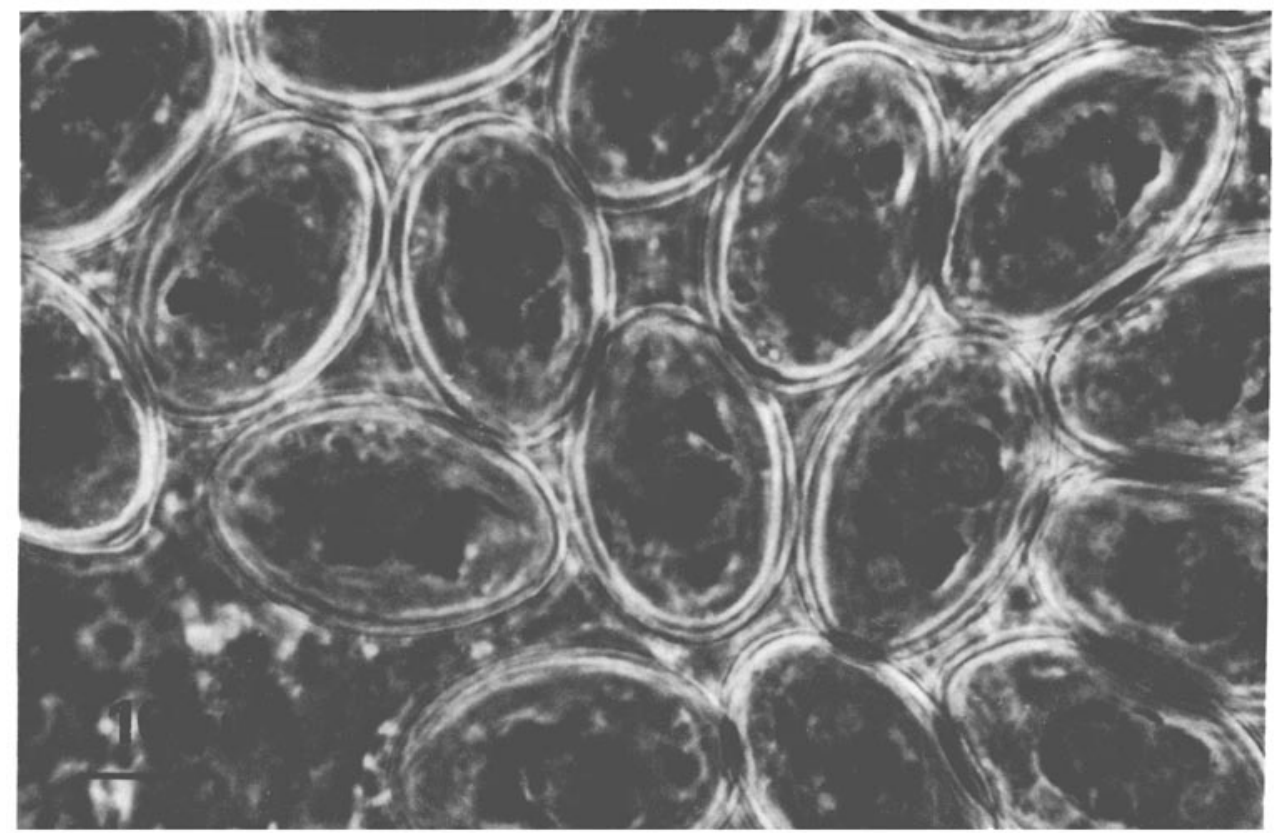

Fig. 4. Embryonated eggs of Heterophyes heterophyes inside the uterus of a fluke 
of the cat and dog population were infected. According to recent reports from Greece (Himonas, 1968, 1977), $16 \%$ ( $n: 186$ ) of the examined stray dogs and $6 \%(n: 123)$ of stray cats of the city of Thessaloniki were found to be infected by $H$. heterophyes.

\section{CONCLUSIONS}

Laboratory experiments with 16 different definitive hosts (Taraschewski, in prep.) have shown (Table 3) that (besides humans) probably only Canidae and cats are susceptible to Heterophyes infection; in these animals the flukes reach a life span of

Table 3. Susceptibility of different definitive hosts to infection by Heterophyes heterophyes

\begin{tabular}{|c|c|c|c|c|}
\hline Hosts & $\begin{array}{c}\text { No. of animals } \\
\text { sacrificed }\end{array}$ & $\begin{array}{l}\text { Flukes reach } \\
\text { sexual maturity }\end{array}$ & $\begin{array}{l}\text { Days of } \\
\text { life span }\end{array}$ & $\begin{array}{l}\text { Recovery rates } \\
(\%)(3-25 \text { d p.i. })\end{array}$ \\
\hline Macaca inus & 2 & - & $<12$ & $0-15$ \\
\hline Rattus norvegicus & 5 & - & $<16$ & $0-94$ \\
\hline R. tiomanicus & 7 & - & $<18$ & $0-71$ \\
\hline R. ratfus & 5 & - & $<8$ & $0-29$ \\
\hline Canis familiaris & 5 & + & $\sim 60$ & $61-83$ \\
\hline Alopex lagopus & 4 & + & $>23$ & $66-93$ \\
\hline Vulpes vulpes & 7 & + & -60 & $55-91$ \\
\hline Felis catus & 14 & + & $60-120$ & $32-81$ \\
\hline Meles meles & 1 & - & $<6$ & 0 \\
\hline Mustela putorius furo & 4 & - & $<3$ & 0 \\
\hline Martes foina & 1 & - & $<6$ & 1 \\
\hline Sus scrofa & 2 & - & $<14$ & $0-12$ \\
\hline Egretta gularis & 2 & - & $<3$ & 0 \\
\hline \multicolumn{5}{|l|}{ Ardeola ibis $x$} \\
\hline Nycticorax nycticorax & 1 & - & $<9$ & 0 \\
\hline Larus argentatus & 4 & - & $<9$ & $0-30$ \\
\hline L. ridibundus & 3 & - & $<3$ & 0 \\
\hline
\end{tabular}

about 2 to 4 months. Considering the larger size and greater amount of uterine eggs, Canidae turned out to be better hosts than cats. In all the other hosts uterine eggs did not become embryonated and life span did not exceed 14 days.

As flukes from the human intestine were found to have a similar size to those from dogs (Kuntz \& Chandler, 1956a), humans can be considered suitable hosts.

Besides dogs and cats, Canis aureus, Vulpes vulpes, Felis chaus and Milvus migrans may also act as reservoir hosts (these species besides dogs and cats were found naturally infected by Wells \& Randall, 1956). However, probably only dogs serve as important reservoir hosts. Cats do not defecate on wet substrate and, as the Egyptian human population rapidly increases, wild animals are becoming rare.

According to Ito (1964), in Japan Metagonimus yokogawai is found more frequently in dogs than in humans. For $H$. heterophyes this observation can be confirmed in respect to the prevalence of this fluke in India or in Greece for instance. In Egypt, however, it is uncertain whether dogs or humans act as the predominant definitive hosts. 


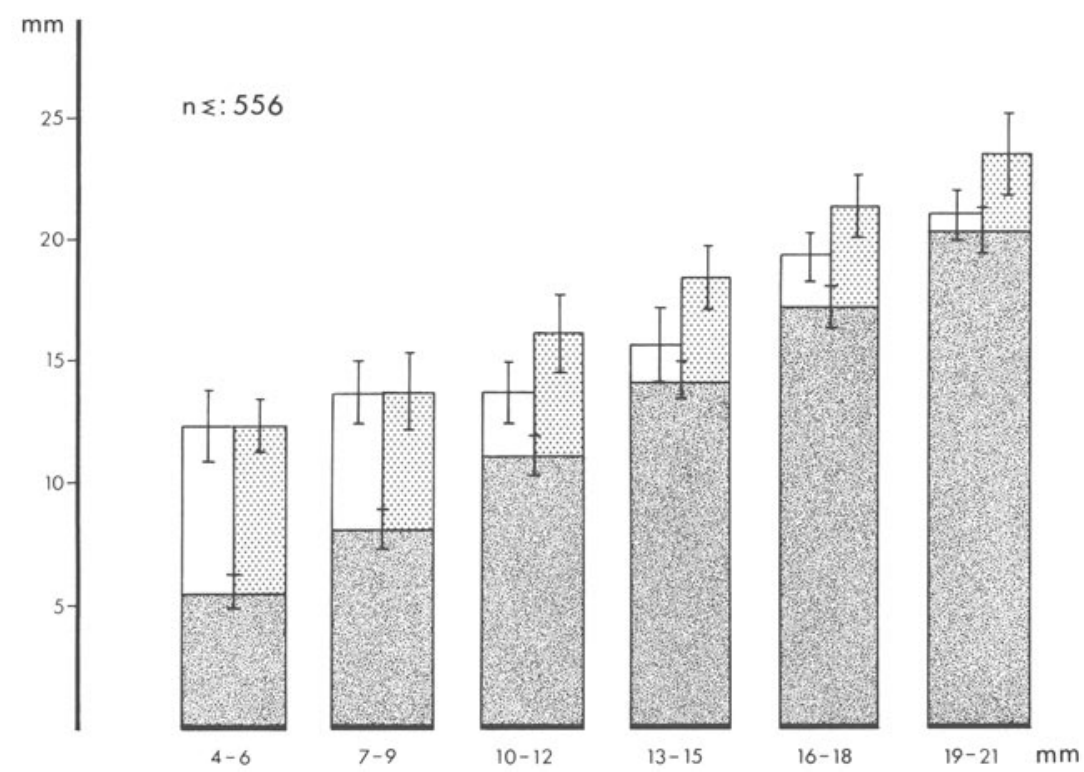

Fig. 5. Growth of $P$. conica naturally infected by heterophyids ( $H$. heterophyes, H. aequalis, Stictodora sawakinensis) within 2 months. Ordinate: snail length in $\mathrm{mm}_{\text {; }}$ abscissa: initial length of snails in mm; base column: initial length; undotted column: growth of uninfected snails ( $\mathrm{nn}$ : 297); dotted column: growth of infected snails ( $\Sigma$ n: 259)

\section{Host-parasite relations}

Little investigation has been conducted on the question of how intermediate and definitive hosts of $H$. heterophyes are affected by the fluke.

\section{Snails}

After the snails have ingested the fluke eggs, the embryonic development of $H$. heterophyes is presumably similar to that of $H$. aequalis, described by Kuntz \& Chandler (1956b). Rediae, producing cercariae, were found inside the digestive glands (Taraschewski \& Paperna, 1981). From growth experiments with snails naturally infected with heterophyids ( $H$. heterophyes, $H$. aequalis, Stictodora sawakinensis), it becomes conspicuous that below $10 \mathrm{~mm}$ initial size, growth of infected and of uninfected specimens was about the same (Fig. 5). Above $10 \mathrm{~mm}$ initial length, infected snails showed enhanced growth when compared to the uninfected snails (Taraschewski, 1980). Thus it can be suspected that heterophyid trematodes have some detrimental influence on reproduction of Pirenella conica, as was shown in other relationships between snails and flukes.

\section{Fish}

Nothing is known about the pathogenicity of $H$. heterophyes inside the second intermediate hosts. There is only one investigation available on Stellantchasmus falcatus infections in Mugil cephalus (Lee \& Cheng, 1970). These authors reported that "the presence of the parasite, even when unencysted, results in the necrotic degeneration of 
the surrounding muscle cells, especially those situated at the anterior or posterior ends of the parasite. Large, vacuolated fat cells ... are usually found filling the spaces vacated by necrotic muscle cells" (Lee \& Cheng, 1970).

As those mullets highly infected with Heterophyes metacercariae, reported by Paperna \& Overstreet (1981), were still found alive, one may conclude that the viability of mullets is not much affected by the presence of the Heterophyes metacercariae in their muscles. Still, investigation on the pathogenicity of Heterophyes heterophyes in different fish hosts is needed.

Metacercariae in experimentally infected Gambusia affinis (Khalil, 1937) and Tilapia (Sarotherodon) mossambica (Taraschewski, 1984) became infective about 20 days post infectionem.

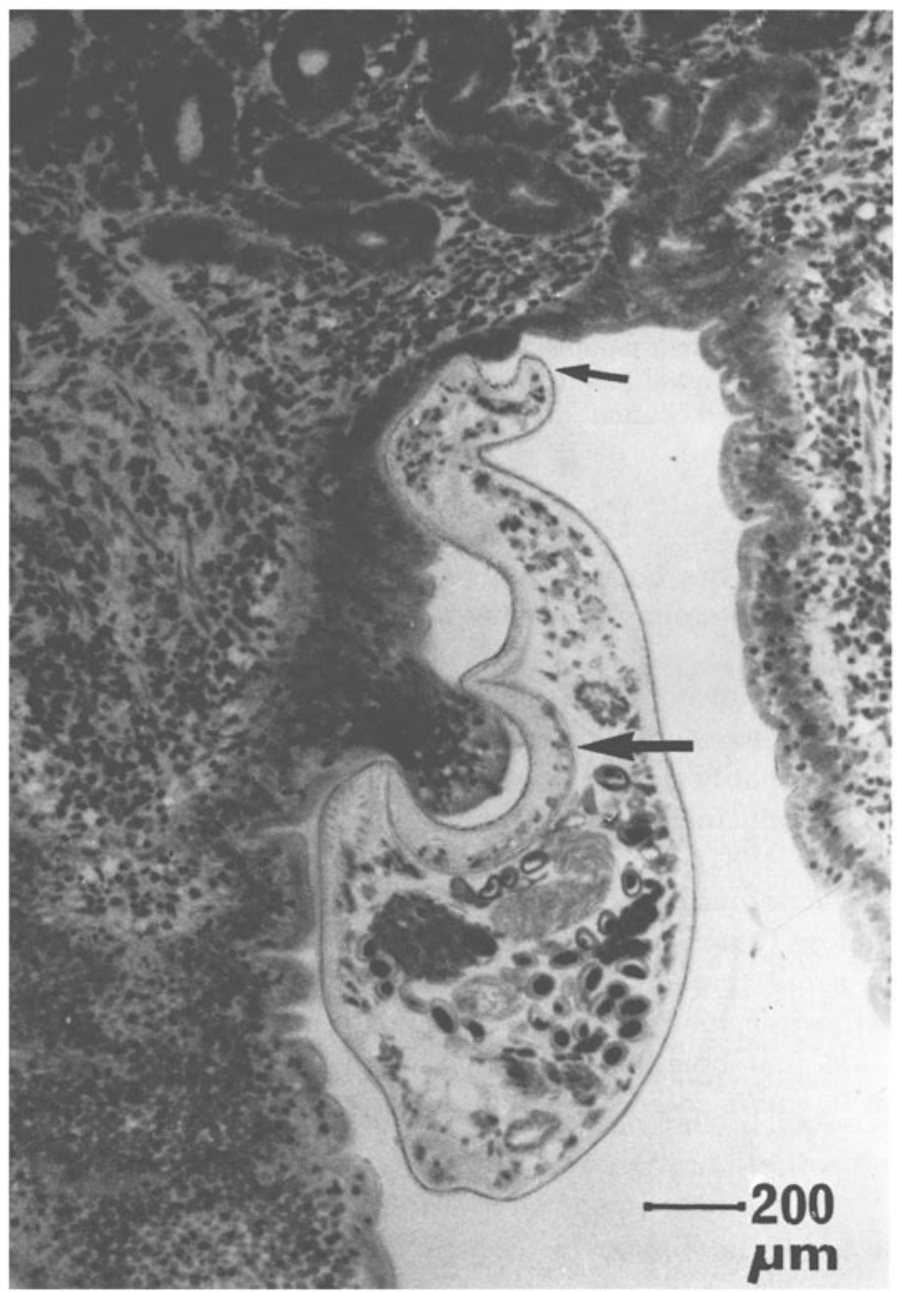

Fig. 6. Heterophyes spec. in small intestine of a cat. Big arrow: ventral sucker clinging to host mucosa; small arrow: oral sucker feeding on host tissue 


\section{Definitive hosts}

Inside experimentally infected definitive hosts, metacercariae of $H$. heterophyes were shown (dogs: Khalil, 1937; cats: Taraschewski, 1984) to excyst about 4 h after oral application. Excystment took place in the upper small intestine (Taraschewski, 1984) or in the duodenum (Khalil, 1937). From H. heterophyes (Hamdy \& Nicola, 1981), Metagonimus yokogawai (Ito, 1964) and Haplorchis yokogawai (Africa et al, 1940) it has been described that after excystment, the juvenile flukes penetrate into the intestinal glands or into the tissue of the mucosa. After a few days they normally return to the intestinal lumen, where they adhere to the mucosa by their ventral sucker (Fig. 6). By means of their oral sucker they feed on the host's mucosal tissue (Fig. 6).

From the data on $H$. heterophyes, it seems that the place of primary attachment to the mucosa is in the same part of the small intestine as the place of excystment where the flukes are still found one or two months later (in suitable hosts) (Taraschewski, 1984). When the site of attachment of juvenile flukes $3 \mathrm{~d}$ p.i. (days post infectionem) is compared to that of sexually mature flukes $10-120 \mathrm{~d}$ p.i. it appears that - due to the intestinal motility - they are just passively carried slightly backwards (Fig. 7). Independent of the species of host, $H$. heterophyes generally prefers the middle part of the small intestine (Fig. 7).

In some cases, sexually mature heterophyids were found stuck in the intestinal wall, from where their eggs could be infiltrated into different organs by way of the blood stream or lymphatic system (see review by Ito, 1964). In Japan, where Metagonimus yokogawai is the most prevalent heterophyid species, nothing is known about fatal human cases due to such eggs (Ito, 1964). In the Philippines, however, where Haplorchis yokogawai is the most prevalent species in humans, Africa et al. (1940) estimated that $15 \%$ of the fatal heart cases resulted from heterophyid myocarditis. In a series of papers,

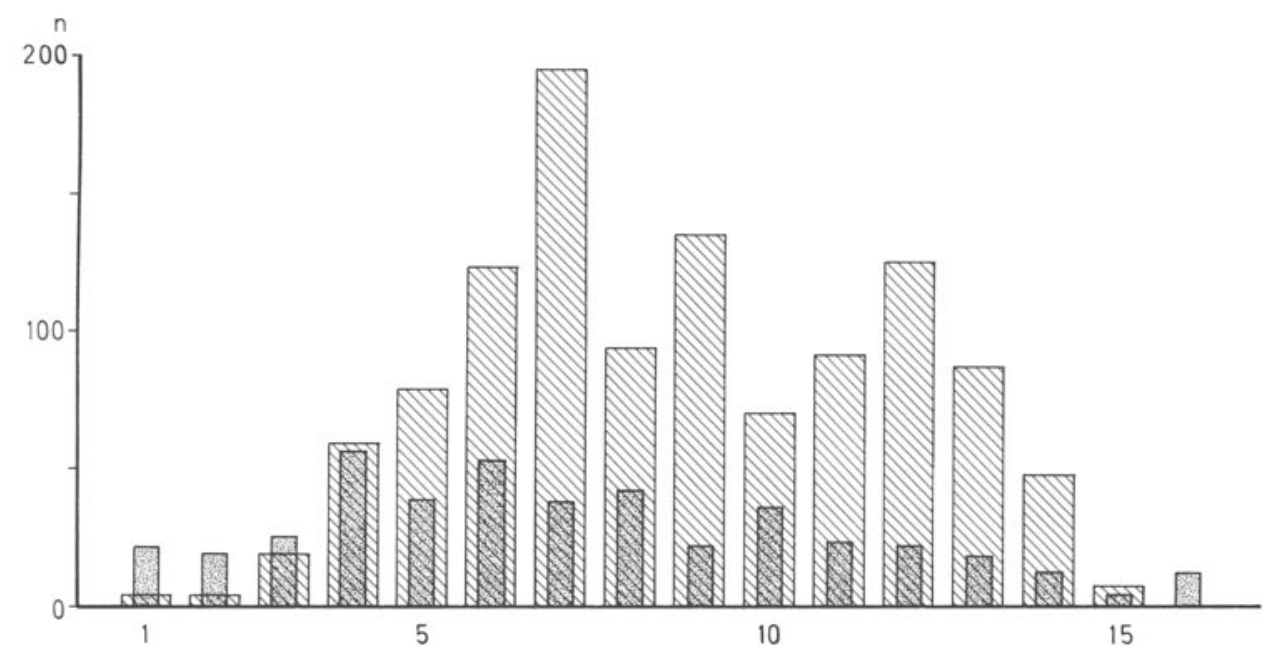

Fig. 7. Distribution of juvenile and mature Heterophyes heterophyes throughout the small intestine of experimentally infected definitive hosts. Ordinate: $\mathbf{n}$ flukes; abscissa: 16 segments of small intestine. Narrow striped bars = Juvenile flukes (3 d p.i., n: 358 from 9 cats and 3 foxes). Broad dotted bars $=$ Mature flukes $(10-120 \mathrm{~d}$ p.i, n: 862 from 9 cats and 3 foxes) 
summarized in 1940, these authors reported many findings of heterophyid eggs in the tissues of human beings autopsied in the Philippines.

Only in two cases were eggs, assigned to $H$. heterophyes, found encapsulated in the human brain (Collomb et al., 1960). In another case, an egg attributed to $H$. nocens was detected inside a tumor of an inflamed appendix (Ito, 1964).

Symptoms of intestinal heterophyiasis seem to be - as usual - dependent on the intensity of infection. Heavy infections, according to Khalil (1937), are accompanied by abdominal discomfort, nausea, headache, vomiting, diarrhea, and sometimes dysentery. Similar symptoms are described for human infections by Metagonimus yokogawai, where the literature is much more comprehensive (Ito, 1964).

Experimentally infected dogs started defecating eggs (Fig. 4) of $H$. heterophyes $8 \mathrm{~d}$ p.i. (Witenberg, 1929); experimentally infected cats on day 9 (Khalil, 1937). Assumably the prepatent period also in humans will be about 7 days, while flukes may have a life span of 1 to 4 months, as shown from infected Canidae and cats (Table 3).

Acknowledgement. Thanks are due to Prof. B. Loos-Frank for critical revision of the manuscript and reading the proofs.

\section{LITERATURE CITED}

Abdel Azim, M., 1938. On the intestinal helminths of dogs in Egypt. - J. Egypt. med. Ass. 21, 118-122.

Africa, C. M., 1938. Description of three trematodes of the genus Haplorchis (Heterophyidae) with notes on two other Philippine members of this genus. - Philipp. J. Sci. 66, 299-307.

Africa, C. M., Leon, W. de \& Garcia, E. Y., 1940. Visceral complications in intestinal heterophyidiasis of man. - Int. Congr. Microbiol. 3, 447-449.

Asada, J., 1928. Studies on human trematodes of the genus Heterophyes occuring in Japan I. Determination of the first intermediate host of Heterophyes heterophyes. - Tokyo med. News $2564,6-12$.

Babbott Jr., F. L., Frye, W. W. \& Gordon, J. E., 1961. Intestinal parasites of man in arctic Greenland. Am. J. trop. Med. Hyg. 10, 185-190.

Balozet, L. \& Callot, J., 1939. Trematodes de Tunisie, 3. Superfamille Heterophyoidea. - Archs Inst. Pasteur Tunis 28, 34-63.

Coble, Y. D., Schulert, A. S., Davis, J. T. \& Awad, A. Y., 1968. Blood, urine and parasitological examinations in male Egyptian oasis subjects. - Trop. geogr. Med. 20, 119-126.

Crawford, G. I, 1948. The Armstrong College zoological expedition to Siwa Oasis (Libyan Desert) 1935. 4: Mollusca. - Egypt. Acad. Sci., Cairo, 116, 45-58.

Collomb, H., Deschiens, R. \& Demarchi, J., 1960. Sur deux cas de distomatose cérébrale à Heterophyes heterophyes. - Bull. Soc. Path. Exot. 53, 144-147.

Deiana, S., 1961. Phagicola italica (Alessandrini, 1906) ed Heterophyes heterophyes (Siebold, 1852) parasiti del cane in Sardegna. - Riv. Parassit. 22, 185-192.

Dissanaike, A. S., 1961. On some helminths of dogs in Colombo and their bearing on human infections, with a description of a new trematode Heterophyopsis yehi sp. nov. (Heterophyidae). - Ceylon J. med. Sci. 10, 1-12.

Evans, G., Murray, J. W., Biggs, J. E. J., Bate, R. \& Bush, P. R., 1973. The oceanography, ecology, sedimentology and geomorphology of parts of the Trucial Coast Barrier Island complex, Persian Gulf. - In: The Persian Gulf. Ed. by B. H. Purser, Springer, Berlin, 233-277.

Fahmy, M. A. M. \& Selim, M. K, 1959. Studies on some trematode parasites of dogs in Egypt with special reference to the role played by fish in their transmission. - Z. ParasitKde 19, 3-13.

Hamdy, E. J. \& Nicola, E., 1981. On the histopathology of the small intestine in animals experimentally infected with $H$. heterophyes. - J. Egypt. med. Ass. 63, 179-184.

Himonas, C. A., 1964. Heterophyes heterophyes from dogs in Greece. - J. Parasit. 50, 799. 
Himonas, C. A., 1968. The parasitic helminths of dog in Greece and their public health importance. (Greek, English summary). University of Thessaloniki, 159-390.

Himonas, C. A., 1977. Ober die Parasitenfauna der Katze in Griechenland. (Greek, German summary). University of Thessaloniki, 1-177.

Ibrahim, A. N, 1975. On the molluscan fauna of the Siwa Oasis. - Bull. zool. Soc. Egypt 27,71-77.

Ito, $J_{;}$1964. Metagonimus and other human heterophyid trematodes. - Progr. med. Parasit. Jap. 1, 315-398.

Kagei, N., Oshima, T., Ishikawa, K. \& Kihata, M., 1964. Two cases of human infection with Stellantchasmus falcatus Onji \& Nishio, 1915 (Heterophyidae) in Kochi Prefecture. (Japan, Engl. summary). - Jap. J. Parasit. 13, 472-478.

Khalil, M. B., 1923. A preliminary note on the second intermediate host of Heterophyes in Egypt. - J. Helminth, 1, 141-142.

Khalil, M. B., 1937. The life-history of the human trematode parasite "Heterophyes heterophyes", Int. Congr. Zool. 12 (3), 1989-2002.

Kuntz, R. E. \& Chandler, A. C., 1956a. Studies on Egyptian trematodes with special reference to the heterophyids of mammals. I. Adult flukes, with descriptions of Phagicola longicollis $\mathrm{n}$. $\mathrm{sp}$., Cynodiplostomum namrui n. sp., and a Stephanoprora from cats. - J. Parasit. 42, 445-459.

Kuntz, R. E. \& Chandler, A. C., 1956 b. Studies on Egyptian trematodes with special reference to the heterophyids of mammals. II. Embryonic development of Heterophyes aequalis Looss. - J. Parasit. 42, 613-625.

Lee, F. O. \& Cheng, T. C., 1970. The histochemistry of Stellantchasmus falcatus Onji \& Nishio, 1915 (Trematoda: Heterophyidae) metacercarial cyst in the mullet Mugil cephalus L. and histopathological alterations in the host. - J. Fish Biol. 2, 235-243.

Looss, A., 1902. Notizen zur Helminthologie Egyptens V. Eine Revision der Fasciolidengattung Heterophyes Cobb. - Zbl. Bakt. ParasitKde. (Abt. 1: Orig.) 1, 886-891.

Manning, G. S. \& Lertprasert, P., 1970. Four new trematodes of man from Thailand. - Transact. R. Soc. trop. Med. Hyg. 65, 101-102.

Manning, G. S., Lertprasert, P., Watanasirmkit, K. \& Chetty, C., 1971. A description of newly discovered intestinal parasites endemic to northeast Thailand. - J. med. Ass. Thailand $54_{f}$ $466-475$.

Maplestone, P. A. \& Bhaduri, N. V., 1940. The helminth parasites of dogs in Calcutta and their bearing on human parasitology. - Indian J. med. Res. 28, 595-604.

Martin, W. E., 1959. Egyptian heterophyid trematodes. - Trans. Am. microsc. Soc. 1959, $172-181$.

Martin, W. E. \& Kuntz, R. E., 1955. Some Egyptian heterophyid trematodes. - J. Parasit, 41, 374-382.

Massoud, J., Jalali, H. \& Reza, M., 1982. Studies on trematodes of the family Heterophyidae (Odhner, 1914) in Iran: 1. Preliminary epidemiological surveys in man and carnivores in Khuzestan. - J. Helminth. 55, 255-260.

Mimioglu, M., Güralp, N. \& Sayin, F., 1959. Ankara köpeklerinde görülen parazit türleri ve bunlarin yayilis nisbeti, - Vet. Fak. Derg. Ankara Univ. 6, 53-68. (Turkish, Engl. summary)

Nagathy, H. F. \& Khalil, H. M., 1964. Incidence of helminth infection among the out-patients in the clinic Matarria collective unit, Dakahlia Governate, U.A.R. - J. Egypt. med. Ass. 47, 341-346.

Paperna, I. \& Overstreet, R. M., 1981. Parasites and diseases of mullets (Mugilidae). In: Aquaculture of grey mullets. Ed. by O. H. Oren. Cambridge Univ. Press, Cambridge, 411-493.

Rajasekariah, G. R. Hedge, K. S. \& Abdul Rahman, S., 1974. Occurrence of trematodes of zoonotic importance in dogs of Banglore. - Mysore J. agric. Sci, 8, 593-596.

Rao, M. A. N. \& Ayyar, L. S. P., 1932. Heterophyes species from dogs in Madras, - Indian vet. J. 8 , 251-253.

Rao, B. V. \& Anantaraman, M, 1967. On the incidence of trematodes of the family Heterophyidae from dogs and cats in India. $-\mathrm{J}$. Helminth. 41, 211-216.

Rifaat, M. A., Salem, S. A., El Kholy, S. J., Hegazi, M. M. \& Yousef, M., 1980. Studies on the incidence of Heterophyes heterophyes in Dakahlia Governate. - J. Egypt. Soc. Parasit. 10, 369-373.

Saito, S., 1973. On the differences between Metagonimus yokogawai and Metagonimus takahashii: II. The experimental infections of the second intermediate hosts. (Japanese, Engl. summary). Jap. J. Parasit. 22, 39-44.

Sakai, Y., 1962. On Metagonimus yokogawai Katsurada, 1912 and Metagonimus yokogawai 
takahashii Suzuki, 1930, especially on their fish intermediate hosts and human infection in Chugoku district. (Japanese, Engl. summary). - Jap. J. Parasit. 11, 421-426.

Segal, D. B., Humphrey, J. M., Edwards, S. J. \& Kirby, M. D., 1968. Parasites of man and domestic animals in Vietnam. Thailand, Laos, and Cambodia. - Expl Parasit. 23, 412-464.

Sen, H. G., 1965. Heterophyes heterophyes from a dog in the western part of India. - Trans. R. Soc. trop. Med. Hyg. 59, 610 .

Seo, B. S., Hong, S. T. \& Chai, J. Y., 1981. Studies on intestinal trematodes in Korea III. Natural human infections of Pygidiopsis summa and Heterophyes heterophyes nocens. - Seoul J. Med. $22,228-235$.

Sheir, Z. M. \& El-Shabrawy Aboul-Enein, M., 1970. Demographic, clinical and therapeutic appraisal of heterophyiasis. - J. trop. Med. Hyg. 76, 148-152.

Siebold, C. T. E., 1852. Ein Beitrag zur Helmintholographia humana, aus brieflichen Mitteilungen des Dr. Bilharz in Cairo, nebst Bemerkungen. - Z. wiss. Zool. 4, 53-76.

Tantachamrum, T. \& Kliks, M., 1978. Heterophyid infection in human ileum: report of three cases.Southeast Asian J. trop. Med. Hyg. 9, 228-231.

Taraschewski, H. 1980. Trematode infections in Pirenella conica collected at the coasts of the Sinai Peninsula. - Zbl. Bakt. ParasitKde (Abt. 1: Ref.) 267, 307-308.

Taraschewski, H* 1984. Die Trematoden der Gattung Heterophyes, Taxonomie, Biologie, Epidemiologie. Diss. Univ. Hohenheim, $169 \mathrm{pp}$.

Taraschewski, H. \& Paperna, I., 1981. Distribution of the snail Pirenella conica in Sinai and Israel and its infection by Heterophyidae and other trematodes. - Mar. Ecol. Prog. Ser. 5, 193-205.

Taraschewski, H. \& Paperna, I., 1982. Trematode infections in Pirenella conica in three sites of a Mangrove lagoon in Sinai. - Z. ParasitenKde 67, 165-173.

Vohra, F. C., 1970. Some studies on Cerithidea cingulata (Gmelin 1790) on a Singapore sandy shore. - Proc. malac. Soc. Lond. 39, 187-201.

Wells, W. H. \& Blagg, W., 1956. A survey of human intestinal parasites in a fishing village of northern Egypt. - Am. J. trop. Med. Hyg. 5, 266-268.

Wells, W. H. \& Randall, B. H., 1956. New hosts for trematodes of the genus Heterophyes in Egypt.J. Parasit. 42, 287-292.

Witenberg, G, 1929. Studies on the trematode-family Heterophyidae, - Ann, trop. Med. Parasit. 23, 131-239.

Witenberg, G., 1932. Fish as a source of worm disease in men. (Hebrew, Engl. summary.) - Harefuah $3,127-139$.

Yokogawa, M., Sano, M., Itabashi, T. \& Kachi, S., 1965. Studies on the intestinal flukes II. Epidemiological studies on heterophyid trematodes of man in Chiba Prefecture. - Jap. J. Parasit. 14, 577-585. 